\title{
Gambaran Kadar Asam Urat pada Pasien Penyakit Ginjal Kronik Stadium 5 yang Belum Menjalani Hemodialisis
}

\author{
${ }^{1}$ Inri N. R. I. Mantiri \\ ${ }^{2}$ Glady I. Rambert \\ ${ }^{2}$ Mayer F. Wowor
}

\begin{abstract}
${ }^{1}$ Program Studi Pendidikan Dokter Fakultas Kedokteran Universitas Sam Ratulangi Manado
${ }^{2}$ Bagian Patologi Klinik Fakultas Kedokteran Universitas Sam Ratulangi Manado

Email: ryokomantri@gmail.com
\end{abstract}

\begin{abstract}
Uric acid is the end product of purine metabolism derived from metabolism in the body and from outside the body (food source). Hyperuricemia is a condition of uric acid level above normal $(3.5-7 \mathrm{mg} / \mathrm{dL}$ in males and $2.6-6 \mathrm{mg} / \mathrm{dL}$ in females). Hyperuricemia due to renal diseases is a risk factor of the progressivity of the disease. This study was aimed to obtain the profile of uric acid level in patients with stage 5 non-dialysis chronic kidney disease (CKD). This was a descriptive observational study. Samples were 35 blood samples of in-patients and out-patients with stage 5 non-dialysis CKD at Prof. Dr. R. D. Kandou Hospital and Advent Hospital Manado during Deember 2015 to January 2016. The laboratory test showed that 80\% of patients had increased uric acid levels $>7 \mathrm{mg} / \mathrm{dL}$. Conclusion: Most patients with stage 5 non-dialysis chronic kidney disease had increased uric acid levels.
\end{abstract}

Keywords: uric acid, stage 5 non-dialysis chronic kidney disease

\begin{abstract}
Abstrak: Asam urat merupakan produk akhir metabolism purin yang berasal dari baik dari metabolism dalam tubuh dan berasal dari luar tubuh (makanan). Hiperurisemia adalah keadaan dimana kadar asam urat darah di atas nilai normal $(3,5-7 \mathrm{mg} / \mathrm{dL}$ pada pria dan 2,6-6 mg/dL pada wanita). Hiperuresemia yang disebabkan oleh penyakit ginjal dianggap sebagai factor risiko progresivitas penyakit ginjal. Penelitian ini bertujuan untuk mengetahui gambaran kadar asam urat pada pasien penyakit ginjal kronik stadium 5 non-dialisis. Jenis penelitian ialah deskriptif observasional. Sampel penelitian ialah sampel darah dari semua pasien rawat jalan maupun rawat inap yang menderita penyakit ginjal kronik stadium 5 non-dialisis dalam kurun waktu Desember 2015-Januari 2016 di RSUP Prof. Dr. R. D. Kandou dan RS Advent Manado. Hasil pemeriksaan laboratorium dari 35 pasien yang terdiagnosis penyakit ginjal kronik stadium 5 non-dialisis memperlihatkan peningkatan kadar asam urat $>7 \mathrm{mg} / \mathrm{dL}$ pada $80 \%$ sampel. Simpulan: Terdapat peningkatan kadar asam urat pada sebagian besar pasien penyakit ginjal kronik stadium 5 non-dialisis.
\end{abstract}

Kata kunci: asam urat, penyakit ginjal kronik stadium 5 non dialisis

Asam urat merupakan produk akhir metabolisme purin yang berasal dari metabolisme dalam tubuh/ faktor endogen (genetik) dan berasal dari luar tubuh/ faktor eksogen (sumber makanan). Asam urat dihasilkan oleh setiap makhluk hidup sebagai hasil dari proses metabolisme sel yang berfungsi untuk memelihara kelangsungan hidup. ${ }^{1}$ Peningkataan kadar asam urat dapat mengakibatkan gangguan pada tubuh manusia seperti pada daerah persendian dan sering disertai timbulnya rasa nyeri. Hal ini disebabkan oleh penumpukan kristal dalam sendi yang terjadi akibat adanya peningkatan kadar asam urat dalam darah; penyakit ini disebut penyakit gout. $^{2}$

Pada penelitian sebelumnya di 
Bumiayu bulan Januari sampai Maret 2008 tercatat 220 orang dan sekitar 52 orang $(22,8 \%)$ mengalami kadar asam urat di atas normal; bulan Mei sampai Juli 2008 tercatat 121 orang yang memeriksakan kadar asam uratnya dan dari semua pemeriksaan ditemukan 36 orang atau $(29,75 \%)$ yang mengalami kadar asam urat di atas normal. Dari data tersebut didapat bahwa selama kurun waktu 3-4 bulan ditemukan kenaikan pemeriksaan kadar asam urat dengan hasil di atas normal sebesar $6,95 \% .^{3}$

Hiperurisemia disebabkan oleh sintesis purin berlebih dalam tubuh karena pola makan yang tidak teratur dan proses pengeluaran asam urat dari dalam tubuh yang mengalami gangguan. ${ }^{2,3}$ Peningkatan kadar asam urat dalam urin disebut urikosuria. Asam urat akan mengalami supersaturasi dan kristalisasi dalam urin yang akan menjadi batu saluran kencing (BSK) sehingga menghambat sistem sekresi dan ekskresi dari fungsi ginjal. Eksresi asam urat dalam urin tergantung pada kadar asam urat dalam darah, filtrasi glomerulus, dan sekresi tubulus asam urat ke dalam urin. Asam urat kurang mengalami saturasi pada suasana urin yang asam. Ketika $\mathrm{pH}$ urine naik maka asam urat tidak mengalami kristalisasi dan tidak akan membentuk batu. ${ }^{4}$

Hiperuresemia adalah keadaan dimana seorang mengandung kadar asam urat di atas nilai normal yaitu 3,5-7 $\mathrm{mg} / \mathrm{dl}$ pada pria dan 2,6-6 mg/dl pada wanita. Kriteria hiperuresemia menurut Council for International Organization of Medical Sciences (CIOMS) ialah $>7 \mathrm{mg} / \mathrm{dL}$ untuk laki-laki dan $>6 \mathrm{mg} / \mathrm{dL}$ untuk perempuan. Hiperurisemia atau peningkatan kadar asam urat dalam darah yang disebabkan oleh penyakit ginjal dianggap sebagai faktor risiko progresivitas penyakit ginjal., ${ }^{4,5}$

Kadar asam urat dalam darah ditentukan oleh keseimbangan antara produksi dan ekskresi. Bila keseimbangan ini terganggu maka dapat menyebabkan peningkatan kadar asam urat dalam darah atau hiperurisemia. Penderita akan cenderung mengalami pirai (gout). Penyebab hiper- urisemia karena produksi yang berlebihan atau ekresi yang menurun ditemukan antara lain pada penyakit ginjal kronik. ${ }^{6,7}$

Ginjal sebagai tempat pengeluaran sisa-sisa zat metabolisme tubuh berfungsi untuk menyeimbangkan cairan dalam tubuh dan terhindar dari zat-zat berbahaya. Proses pengeluaran zat-zat sisa pada ginjal terdiri dari fase filtrasi oleh glomerulus, fase reabsorbsi melalui tubuli dan terakhir fase ekskresi oleh tubuli kolektivus. Pada penyakit ginjal kronik (PGK) terjadi pengurangan massa ginjal dan penurunan fungsi ginjal, yang akan menyebabkan gangguan dalam proses fisiologik ginjal terutama dalam hal ekskresi zat-zat sisa, salah satunya asam urat. ${ }^{8}$

Dari daftar 10 penyakit terbanyak di Irina C2 dan C4 RSUP Prof. Dr. R.D. Kandou Manado, PGK menempati peringkat pertama. Pasien PGK pada bulan Mei hingga September 2014 berjumlah 80 orang, pasien laki-laki sebanyak 51 orang dan pasien wanita sebanyak 29 orang. $^{5}$ Berdasarkan hal-hal tersebut peneliti tertarik untuk melakukan penelitian mengenai gambaran kadar asam urat pada pasien PGK, mengingat penyakit ini merupakan penyakit yang sering di temukan. Penelitian ini bertujuan untuk mengetahui gambaran kadar asam urat pada pasien PGK stadium 5 non-dialisis.

\section{METODE PENELITIAN}

Penelitian dilaksanakan di Poliklinik RSUP Prof. Dr. R. D. Kandou Manado dan Rumah Sakit Advent Manado pada bulan Desember 2015 sampai Januari 2016. Pemeriksaan kadar asam urat dilakukan di Laboratorium Prokita Manado.

Populasi penelitian ialah individu yang menderita PGK stadium 5 di Poliklinik Nefrologi-Hipertensi dan rawat inap bagian Penyakit Dalam RSUP Prof. Dr. R. D. Kandou Manado dan Rumah Sakit Advent Manado. Sampel diambil dengan cara nonprobability sampling jenis consecutive sampling berupa darah dari semua pasien yang menderita PGK stadium 5 non-dialisis dalam kurun waktu yang telah ditentukan. 


\section{HASIL PENELITIAN}

Penelitian ini dilakukan terhadap pasien PGK stadium 5 non-dialisis di dua rumah sakit di Kota Manado yaitu Poliklinik Nefrologi-Hipertensi dan rawat inap Bagian Penyakit Dalam RSUP Prof. Dr. R. D. Kandou Manado dan Rumah Sakit Advent Manado. Pemeriksaan kadar asam urat sampel darah dilakukan di Laboratorium Prokita. Data yang diperoleh ditampilkan dalam bentuk tabel.

Tabel 1 memperlihatkan distribusi usia pada pasien rawat inap maupun rawat jalan secara keseluruhan. Kelompok usia terbanyak ialah 66-75 tahun $(37,1 \%)$, diikuti oleh kelompok usia 46-55 tahun $(22,9 \%)$, kelompok usia 56-65 tahun $(20,0 \%)$ dan kelompok usia $>75$ tahun $(11,4 \%)$. Tabel 2 memperlihatkan distribusi pasien rawat inap dan rawat jalan yang terdiagnosis PGK stadium 5 non-dialisis sebanyak 35 pasien, terdiri dari 21 orang laki-laki $(60 \%)$ dan 14 orang perempuan (40\%).

Tabel 3 memperlihatkan bahwa dari 35 pasien yang terdiagnosis PGK stadium 5 non-dialisis 29 pasien $(80 \%)$ mengalami peningkatan kadar asam urat $>7 \mathrm{mg} / \mathrm{dl}$. Pada Tabel 4 dan Gambar 1 dapat dilihat dari 35 pasien PGK stadium 5, terdapat 3 pasien rawat inap dan 3 pasien rawat jalan (20\%) dengan nilai asam urat 2,6-7mg/dl; 7 pasien rawat inap dan 4 pasien rawat jalan (34\%) dengan nilai asam urat 7-9,6 mg/dl; dan 7 pasien rawat inap dan 11 pasien rawat jalan $(46 \%)$ dengan nilai asam urat $>9,6 \mathrm{mg} / \mathrm{dl}$.

Pada Tabel 5 terlihat dari 35 pasien yang terdiagnosis PGK stadium 5 non dialisis, terdapat 29 orang dengan riwayat hipertensi $(83 \%), 8$ orang dengan riwayat diabetes mellitus (23\%), 15 orang dengan riwayat asam urat $(43 \%)$, dan 1 orang dengan riwayat penyakit jantung $(3 \%)$.

Tabel 1. Distribusi pasien PGK stadium 5 non-dialisis menurut usia

\begin{tabular}{lcccccc}
\hline \multirow{2}{*}{ Usia } & \multicolumn{6}{c}{ Frekuensi } \\
& \multicolumn{2}{c}{ Rawat inap } & \multicolumn{2}{c}{ Rawat jalan } & \multicolumn{2}{c}{ Total } \\
& Jumlah & $\%$ & Jumlah & $\%$ & Jumlah & $\%$ \\
\hline 26-35 tahun & 1 & $2,9 \%$ & 0 & $0,0 \%$ & 1 & $2,9 \%$ \\
36-45 tahun & 0 & $0,0 \%$ & 2 & $5,7 \%$ & 2 & $5,7 \%$ \\
46-55 tahun & 1 & $2,9 \%$ & 7 & $20,0 \%$ & 8 & $22,9 \%$ \\
56-65 tahun & 3 & $8,6 \%$ & 4 & $11,4 \%$ & 7 & $20,0 \%$ \\
66-75 tahun & 9 & $25,7 \%$ & 4 & $11,4 \%$ & 13 & $37,1 \%$ \\
$>75$ tahun & 4 & $11,4 \%$ & 0 & $0,0 \%$ & 4 & $11,4 \%$ \\
Total & 18 & $51,4 \%$ & 17 & $48,6 \%$ & 35 & $100,0 \%$ \\
\hline
\end{tabular}

Tabel 2. Distribusi pasien PGK stadium 5 non-dialisis menurut jenis kelamin

\begin{tabular}{lcccccc}
\hline \multirow{2}{*}{ Jenis kelamin } & \multicolumn{6}{c}{ Frekuensi } \\
\cline { 2 - 7 } & \multicolumn{2}{c}{ Rawat inap } & \multicolumn{2}{c}{ Rawat jalan } & \multicolumn{2}{c}{ Total } \\
& Jumlah & $\%$ & Jumlah & $\%$ & Jumlah & $\%$ \\
\hline Laki-Laki & 10 & $28,5 \%$ & 11 & $31,4 \%$ & 21 & $60 \%$ \\
Perempuan & 8 & $22,9 \%$ & 6 & $17,2 \%$ & 14 & $40 \%$ \\
Total & 18 & $51,4 \%$ & 17 & $48,6 \%$ & 35 & $100 \%$ \\
\hline
\end{tabular}

Tabel 3. Distribusi pasien PGK stadium 5 non-dialisis menurut hasil pemeriksaan kadar asam urat

\begin{tabular}{ccccc}
\hline Kadar asam urat & Laki-laki & Perempuan & Jumlah & \% \\
\hline $2,6-7 \mathrm{mg} / \mathrm{dl}$ & 5 & 1 & 6 & 20 \\
$7-9,6 \mathrm{mg} / \mathrm{dl}$ & 6 & 5 & 11 & 35 \\
$>9,6 \mathrm{mg} / \mathrm{dl}$ & 10 & 8 & 18 & 45 \\
Total & 21 & 14 & 35 & 100 \\
\hline
\end{tabular}




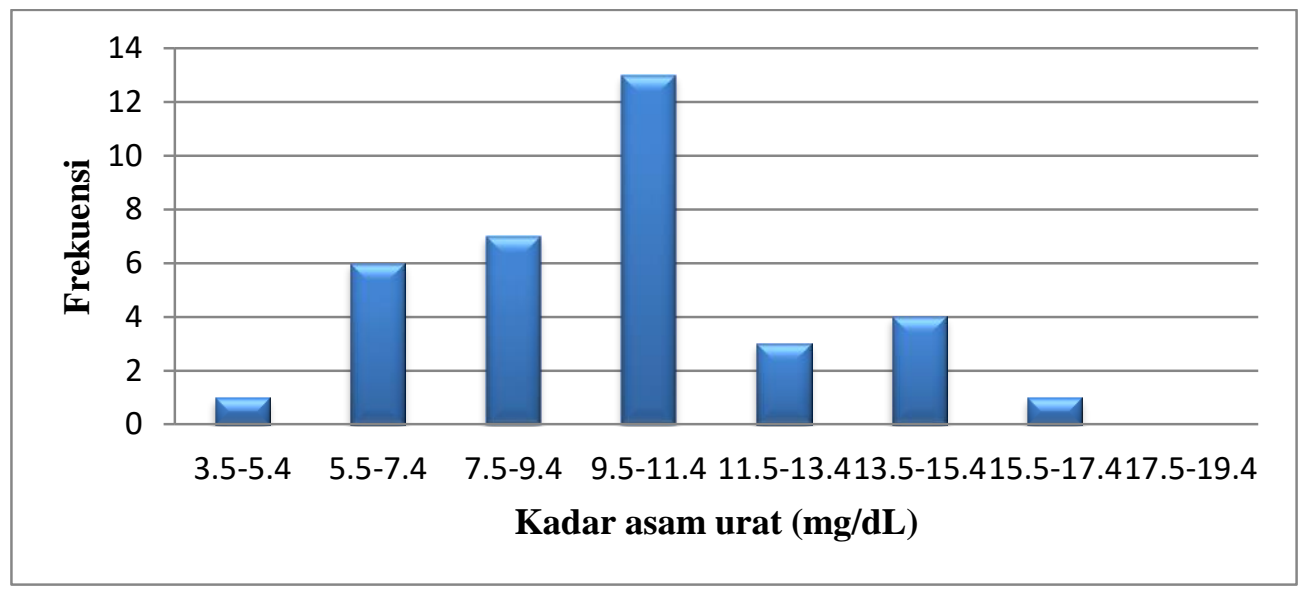

Gambar 1. Distribusi frekuensi hasil pemeriksaan kadar asam urat

Tabel 4. Distribusi hasil pemeriksaan asam urat berdasarkan jenis pelayanan medis

\begin{tabular}{ccccc}
\hline Nilai asam urat & \multicolumn{2}{c}{ Rawat inap } & \multicolumn{2}{c}{ Rawat jalan } \\
& Frekuensi & $\%$ & Frekuensi & $\%$ \\
\hline $2,6-7 \mathrm{mg} / \mathrm{dl}$ & 3 & $10 \%$ & 3 & $10 \%$ \\
$7-9,6 \mathrm{mg} / \mathrm{dl}$ & 7 & $20 \%$ & 4 & $14 \%$ \\
$>9,6 \mathrm{mg} / \mathrm{dl}$ & 7 & $20 \%$ & 11 & $26 \%$ \\
\hline
\end{tabular}

Tabel 5. Distribusi pasien penyakit ginjal kronik stadium 5 non-dialisis menurut riwayat penyakit dahulu

\begin{tabular}{ccc}
\hline Riwayat penyakit dahulu & Jumlah & \% \\
\hline Hipertensi & 29 & $83 \%$ \\
Diabetes melitus & 8 & $23 \%$ \\
Asam urat & 15 & $43 \%$ \\
Penyakit jantung & 1 & $3 \%$ \\
\hline
\end{tabular}

\section{BAHASAN}

Penelitian ini dilakukan untuk mengeahui bagaimana gambaran kadar asam urat pada pasien PGK stadium 5 yang belum menjalani dialisis di Manado. Pelaksanaan penelitian ini berlangsung dari bulan Desember tahun 2015 sampai bulan Januari tahun 2016 yang dilakukan pada dua rumah sakit di Kota Manado, yaitu RSUP Prof. Dr. R.D Kandou Manado dan RS Advent Manado.

Pengambilan sampel dilakukan secara langsung, yaitu sampel darah pada pasien PGK yang berada di instalasi Rawat Inap (IRINA) dan pasien rawat jalan di Poliklinik Penyakit Dalam Bagian Nefrologi-Hipertensi serta catatan rekam medik yang telah dikonfirmasi melalui gejala klinis. Sampel yang diambil diletakkan dalam wadah tanpa koagulan dan langsung dibawa ke laboratorium untuk diperiksa.

Sampel darah yang diperoleh di sentrifugasi untuk mendapatkan serum yang akan dipakai untuk mengukur kadar asam urat. Jumlah pasien PGK yang didapat pada penelitian ini sebanyak 35 orang, di antaranya 18 pasien rawat inap dan 17 pasien rawat jalan yang memenuhi kriteria inklusi. Berdasarkan jenis kelamin diperoleh 14 orang perempuan $(40 \%)$ dan 21 orang laki-laki $(60 \%)$ (Tabel 2).

Berdasarkan distribusi usia didapatkan kelompok usia terbanyak yang menderita PGK stadium 5 non-dialisis ialah 66-75 tahun $(37,1 \%)$ diikuti kelompok usia 46-55 tahun $(22,9 \%)$ (Tabel 1). Hasil penelitian ini tidak banyak berbeda dengan hasil penelitian yang dilakukan oleh Sumigar et al. ${ }^{3}$ di RSUP Prof. Dr. R. D. Kandou 
Manado pada bulan Mei sampai September 2014 yang melaporkan bahwa usia terbanyak pasien PGK stadium 5 yaitu usia $>60$ tahun. Hasil penelitan ini tidak sejalan dengan data statistik United States Renal Data System $^{9}$ pada tahun 2013 yang menunjukkan bahwa kelompok usia 45-46 tahun merupakan kelompok usia dengan prevalensi terbanyak yang menderita PGK stadium 5 yaitu sebesar 292.344 kasus di Amerika. ${ }^{10}$ Hasil penelitian ini juga berbeda dengan data Riset Kesehatan Dasar ${ }^{11}$ (Riskesdas) tahun 2013 yang dipublikasikan oleh Kementerian Kesehatan dalam yang menunjukkan bahwa jumlah pasien tertinggi terdapat pada kelompok usia $\geq 75$ tahun $(0,6 \%)$.

Berdasarkan distribusi jenis kelamin dari 35 pasien PGK stadium 5 non-dialisis baik yang rawat inap maupun rawat jalan, didapatkan pasien laki-laki 21 orang $(60 \%)$ dan pasien perempuan 14 orang (40\%) (Tabel 2) yang menyokong bahwa pasien laki-laki lebih banyak dari pada pasien perempuan. Hasil ini sejalan dengan data United States Renal Data System Annual Data Report ${ }^{10}$ tahun 2013 yang menunjukkan bahwa pasien laki-laki $(56,8 \%)$ lebih banyak dari perempuan $(43,2 \%)$. Hasil ini juga selaras dengan hasil Riskesdas ${ }^{11}$ tahun 2013 yang menunjukkan bahwa prevalensi PGK yang terdiagnosis dokter di Indonesia lebih tinggi pada laki-laki dibandingkan perempuan.

Berdasarkan hasil pemeriksaan kadar asam urat pada pasien PGK (Tabel 3) didapatkan 6 pasien $(20 \%)$ dengan nilai asam urat $2,6-7 \mathrm{mg} / \mathrm{dl}, 11$ pasien $(35 \%)$ dengan nilai asam urat 7-9,6mg/dl, dan 18 pasien (45\%) dengan nilai asam urat $>9,6 \mathrm{mg} / \mathrm{dl}$. Data di atas menunjukkan bahwa $80 \%$ dari 35 pasien yang terdiagnosis PGK stadium 5 non-dialisis mengalami peningkatan kadar asam urat yang menandakan pada pasien tersebut terjadi penumpukan asam urat yang diakibatkan kegagalan fungsi glomeruli atau adanya obstruksi. ${ }^{12}$

Hasil ini sesuai dengan teori yang menyatakan bahwa ginjal merupakan tempat pengeluaran sisa-sisa zat metabolis- me tubuh untuk menyeimbangkan cairan dalam tubuh dan terhindar dari fase ekskresi oleh tubulus kolektivus. Jika terjadi PGK maka terjadi penurunan fungsi ginjal, yang akan menyebabkan gangguan dalam proses fisiologik ginjal terutama dalam hal ekskresi zat-zat sisa, salah satunya asam urat. Dapat disimpulkan bahwa peningkatan kadar asam urat dalam darah lebih banyak disebabkan oleh PGK. ${ }^{3-8}$

Pada PGK terjadi pengurangan massa ginjal dan penurunan fungsi ginjal. Hal tersebut akan menyebabkan gangguan dalam proses fisiologik ginjal terutama dalam hal ekskresi zat-zat sisa salah satunya asam urat. Oleh sebab itu peningkatan kadar asam urat dalam darah dianggap sebagai faktor risiko progresivitas PGK, namun pada keadaan tertentu bisa di temukan pasien PGK dengan kadar asam urat pada tingkat normal yang terjadi di akibatkan pengunaan obat penurun asam urat saat pemeriksaan. ${ }^{4,8,13}$

Hasil penelitian ini menunjukkan bahwa dari 35 pasien PGK stadium 5, terdapat 3 pasien rawat inap dan 3 pasien rawat jalan dengan nilai asam urat 6$7 \mathrm{mg} / \mathrm{dl} ; 7$ pasien rawat inap dan 4 pasien rawat jalan dengan nilai asam urat 7-9,6 $\mathrm{mg} / \mathrm{dl}$; dan 7 pasien rawat inap dan 11 pasien rawat jalan dengan nilai asam urat $>9,6 \mathrm{mg} / \mathrm{dl}$ (Tabel 4). Tampaknya pasien dengan nilai asam urat tinggi, lebih banyak didapatkan pada pasien rawat jalan yang seharusnya menjadi pasien rawat inap.

Berdasarkan adanya penyakit dahulu pada pasien PGK stadium 5 non-dialisis (Tabel 5), dari 35 pasien terdapat 29 orang dengan riwayat hipertensi $(83 \%), 8$ orang dengan riwayat diabetes melitus $(23 \%), 15$ orang dengan riwayat kadar asam urat tinggi (43\%), dan 1 orang dengan riwayat penyakit jantung (3\%). Hasil ini berbeda dengan data statistic United States Renal Data System Annual Data Report ${ }^{10}$ tahun 2013 yang menunjukkan bahwa diabetes (37,9\%) merupakan penyebab terbanyak PGK. Namun hasil tersebut berbeda dengan data statistik $5^{\text {th }}$ Report Indonesia Renal Registry tahun 2012 yang melaporkan bahwa frekuensi pasien dengan hipertensi 
ialah yang tertinggi pada PGK stadium 5 (5654 kasus) diusul dengan diabetes (4199 kasus). Hal ini sesuai dengan data statistik yang menunjukkan bahwa hipertensi (34\%) merupakan penyebab terbanyak PGK stadium $5 .^{10}$

Keterbatasan penelitian ini ialah jumlah subjek yang terkumpul dan persiapan pengukuran pasien masih kurang. Faktor eksternal lain yang mungkin memengaruhi ialah kemungkinan intervensi yang telah dilakukan sebelumnya, baik penyuluhan, diet yang baik, atau obat-obatan akibat komorbid dengan penyakit lain yang dapat memengaruhi kondisi pasien yang diteliti.

\section{SIMPULAN}

Berdasarkan hasil penelitian yang dilakukan di Poliklinik Nefrologi-Hipertensi dan rawat inap bagian Penyakit Dalam RSUP Prof. Dr. R. D. Kandou Manado dan Rumah Sakit Advent Manado dapat disimpulkan bahwa terjadi peningkatan kadar asam urat pada sebagian besar pasien penyakit ginjal kronik stadium 5 non-dialisis.

\section{SARAN}

Perlunya dilakukan penelitian lebih lanjut dengan metode analitik dan jumlah sampel yang lebih besar sehingga bisa mengetahui adanya hubungan sebab akibat antara kedua variabel.

Perlunya dilakukan penelitian lanjut dilengkapi dengan wawancara terhadap pasien mengenai intervensi yang telah diberikan yang dapat memengaruhi kadar asam urat dalam darah.

\section{DAFTAR PUSTAKA}

1. Suwitra K. Penyakit ginjal kronik. In: Sudoyo AW, Setiyohadi B, Alwi I, editors. Buku Ajar Ilmu Penyakit Dalam Jilid II (5th ed). Jakarta: Interna publishing, 2009; p. 1035.

2. Zhang Q, Rothenbacher D. Prevalence of chronic kidney disease in populationbased studies: systematic review. BMC Public Health. 2008;8:117.

3. Sumigar G, Rompas S, Pondaag L.
Hubungan dukungan keluarga dengan kepatuhan diet pada pasien gagal ginjal kronik di irina C2 dan C4 RSUP Prof. Dr. R. D. Kandou Manado. eKep. 2015;3(1):2

4. Miagi C. Gambaran citra tubuh dan tingkat depresi pada remaja penderita penyakit ginjal kronik yang menjalani hemodialisis [Skripsi]. Bandung: Fakultas Psikologi Universitas Padjajaran; 2014.

5. Tandi M, Mongan A, Manoppo F. Hubungan antara derajat penyakit ginjal kronik dengan nilai agregasi trombosit di RSUP Prof. Dr. R. D. Kandou Manado. e-Bm. 2012;2:509

6. Lina N, Setiyono A. Analisis kebiasaan makan yang menyebabkan peningkatan kadar asam urat. Jurnal Kesehatan Komunitas Indonesia. 2014;10:1004-14.

7. Manampiring A, Bodhy W. Prevalensi hiper uresemia pada remaja obes di Kota Tomohon. 20 Desember 2010 [diakses tanggal 16 Oktober 2015]. Diunggah dari:

file:///C:/Users/ASUS/Desktop/Preval ensi_Hiperurisemia_pada_Remaja_Ob ese_Di_Kota_Tomohon.pdf

8. Syukri M. Asam urat dan hiperurisemia. Majalah Kedokteran Nusantara. 2007;40:52-5.

9. Ronco C, Rodeghiero F, editors. Hyperuricemic syndromes: pathophysiology and therapy. Contributions to nephrology Vol. 147. Basel: Karger, 2005.

10. USRD (United States Renal Data System) 2013. USRDS Annual Data Report. [cited 2016 Jan 9]. Available from: http://www.usrds.org/2008/vies/esrd.0 Ob.hp2010.asp.

11. Badan Penelitian dan Pebgembangan Kesehatan Kementerian Kesehatan RI. Riset kesehatan dasar tahun 2013; p. 129-31. [cited 2016 Jan 9]. Available from: www.depkes.go.id.

12. Mandell BF. Clinical manifestations of hyperuricemia and gout. Cleve Clin $\mathbf{J}$ Med. 2008;75 Suppl:S5-8.

13. Steele TH. Hypouricemia. N Engl J Med. 1979;301:549-50. 